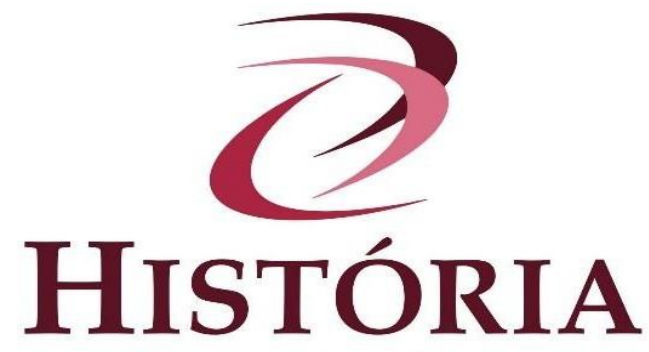

debates e tendências

\title{
"An Investment in Leadership": Rockefeller Foundation Fellowships and the Globalization of Public Health Knowledge, 1915-1940
}

\author{
"Um investimento em Liderança": bolsas da Fundação Rockefeller e a \\ Globalização do Conhecimento em Saúde Pública, 1915-1940
}

\author{
"Una inversion en liderazgo": becas de la Fundación Rockefeller y la \\ Globalización del Conocimento en Salud Pública, 1915-1940
}

Darwin H. Stapleton ${ }^{\mathrm{i}}$

\begin{abstract}
The Rockefeller Foundation, the largest philanthropy in the first half of the 20th century, initiated a global program of fellowships to train public health officials. The majority of the fellows were brought to universities in the United States to study sciencebased medicine for one or more years, followed by field work at research stations funded by the Foundation. Fellows returned to their home countries to serve in public health institutions, and took with them the Foundation's American-style strategies for promoting and implementing public health programs. The public health fellowship program deeply influenced global public health in the 20th century.
\end{abstract}

Keywords: Fellowships. Field stations. Public health. Rockefeller Foundation. Scientific medicine.

Resumo: A Fundação Rockefeller, a maior filantropia da primeira metade do século XX, iniciou um programa global de bolsas para treinar funcionarios da saúde pública. A maioria dos bolsistas foi trazida para Universidades nos Estados Unidos para estudar medicina baseada em ciência por um ou mais anos, seguida por trabalho de campo em estações de pesquisa financiadas pela Fundação. Os bolsistas voltaram a seus países de origem para servir em instituições de saúde pública e levaram consigo as estratégias do estilo americano da Fundação para a promoção e implementação de programas de saúde pública. O programa de bolsas de estudos em saúde pública influenciou profundamente a saúde pública global no século XX.

Palavras-chave: Bolsistas. Estações de campo. Saúde pública. Fundação Rockefeller. Medicina científica.

Resumen: La Fundación Rockefeller, la organización filantrópica más grande de la primera mitad del siglo XX, inició un programa global de becas para capacitar a funccionarios de salud publica. La mayoría de los becarios fueran llevados a universidades de los Estados Unidos para estudiar medicina baseada en la ciencia durante uno o más años, seguido de trabajo de campo en estaciones de investigación financiadas por la Fundación. Los becários regresaron a sus países de origen para trabajar en instituciones de salud publica y se llevaron consigo las estrategias de estilo estadounidense de la Fundación para promover e 
implementar programas de salud pública. El programa de becas de salud pública influyó profundamente en la salud publica mundial en el siglo XX.

Palabras clave: Becas. Estaciones de campo. Salud pública. Fundación Rockefeller. Medicina científica.

Creation of a global conversation on public health in the first half of the twentieth century was substantially a product of the fellowship program of the Rockefeller Foundation and its closely-allied Rockefeller philanthropies, the China Medical Board, and the International Health Board and its successor the International Health Division, which was merged into the Rockefeller Foundation in 1928. ${ }^{\text {ii }}$ The instigation of a global public health conversation also was accomplished by other means, including subventions of international congresses, support of the League of Nations Health Office, the creation of institutes of health and related institutions in several countries, and support of public health research. ${ }^{\text {iii }}$ But the Foundation's most important contribution to the globalization of public health knowledge was the funding of fellowships and the promotion of the fellows' visits to the Foundation's public health research and demonstration sites throughout the world. As Marcos Cueto has pointed out in relation to Latin America, "fellowships were considered [by the Rockefeller philanthropies] an important means for reformulating public health" (CUETO, 1995, p. 225). As touched on at various points in this essay, that was especially true for Brazil.

The Rockefeller Foundation was established in 1913 by John D. Rockefeller, who then was likely the wealthiest businessman in the world, and who made the Foundation the largest philanthropic body of its time (CHERNOW, 1998, p. 556-559, 566). The Foundation's motto was "For the Well-being of Mankind Throughout the World." The Foundation's leaders assessed public health as one of the most pressing problems for mankind, and quickly established programs in that field. They committed to a fellowship program intended to create a generation of public health officials trained to approach public health through a framework of scientific medicine, and within a few years described the fellowship program as "an investment in leadership" (ROCKEFELLER FOUNDATION, 1922, p. 146). The president of the Foundation summarized the significance of fellowships, just as the program went into full operation in 1923, in a letter to the chairman of the Foundation's trustees, John D. Rockefeller Jr.:

All of us who have been concerned with these fellowships are convinced, I think, that there is no more successful means of promoting specific ends and fostering international goodwill than the appointment of individuals to fellowships (VINCENT, 9 November 1923). 
Seven years later, in 1930, the Foundation's annual report continued to identify fellowships as a major contributor to internationalism, stating that:

\begin{abstract}
One of the factors in bringing about the peaceful social revolution represented by the upswing in public health work, especially in Europe, has been the invigorating contacts made by various leaders, young and old, due to fellowships, the travel of health officials, and the interchange of health personnel (...) (ROCKEFELLER FOUNDATION, 1931, p. 105).
\end{abstract}

Clearly, diffusing public health knowledge by fellowships and visits was highly valued by the Rockefeller Foundation and its offices. However, the mechanisms of this twopronged program have not been given much attention by historians. This essay will review the major aspects and results of the program as a contribution to better understanding of the globalization of public health in the $20^{\text {th }}$ century.

\title{
Historiographic Context
}

There are two historiographic frames that provide perspectives for studying the Rockefeller fellowship program. The first is the transnational perspective, which allows historians to override the nation-state as the basic reference for historical narratives. Transnational history promotes the understanding of global institutions and global interconnections, including the activities of global philanthropies such as the Rockefeller Foundation. Transnational historian Pierre-Yves Saunier has argued that:

When we examine interactions, circulations, constellations ... between and through nations with our historical camera set on transnational mode, we also put ourselves in position to capture the flows, ties and formations that have worked across, between and through other kinds of units, beginning with infranational and supranational territorial units (SAUNIER, 2013, p. 10-11).

While proposing that transnational history allows historians to shift their gaze from the nation-state to supranational actors, Saunier also notes the importance of individuals, and stating that "intermediaries, go-betweens and brokers lived and operated in-between large social and political constructions," but "their traces are often peripheral" to the national frameworks that historians tend to rely on (SAUNIER, 2013, p. 36).

The second historiographic frame for understanding the Rockefeller fellowships is the process of the diffusion of knowledge, a concept that refers to the movement of both ideas and skills across national and cultural boundaries in ways such that they can be 
reproduced in a new setting. ${ }^{\text {iv }}$ This is a well-known phenomenon in the history of science and technology in the modern era, ${ }^{\mathrm{v}}$ yet the diffusion of public health knowledge, specifically, has received little attention.

In sum, the Rockefeller fellowship program is a significant instance of the transnational diffusion of knowledge, and was a major element of cultural change in the $20^{\text {th }}$ century, enhancing the international flows of people and knowledge that characterize the era.

\section{Americanization}

The Rockefeller philanthropies certainly wanted to make public health throughout the world more scientific, and less traditionally medical, in its approach, and they wanted to acquaint public health leaders with what the Rockefeller leaders regarded as the latest techniques in measuring the in incidence of diseases and controlling them. ${ }^{\mathrm{vi}}$ But a consequence of fellowships and visits also was what has been referred to as the "Americanization" of global public health - that is, the progressive orientation of public health workers, often through fellowships and organized visits, toward what was perceived as American ways of doing things. Anne-Emanuelle Birn, a student of the Rockefeller influence on $20^{\text {th }}$ century public health in Mexico, has commented that

\footnotetext{
Many of the most lasting changes in the conceptualization and practice of public health in Mexico were effected through the grants the [Rockefeller Foundation] offered to individual health professionals for study in the U.S. ... During the same period [1920-1950] dozens of Mexican health officials, including each incoming Minister of Health, received travel grants to visit North American public health offices and research centers. These administrators would assure that the [International Health Division] models would stay firmly in place and that a new generation of public health offices would be trained similarly (BIRN, 1996, p. 49).
}

\section{Forming the Rockefeller Fellowship Program}

The origins of the Rockefeller fellowship program are early in the history of fellowships as a means of promoting and diffusion scientific knowledge. By the beginning of the $20^{\text {th }}$ century the descriptive term "fellow" was regularly applied to "holders of certain sums of money for a fixed number of years [who were] devoted to special study or research." ${ }^{\text {vii }}$ By extension, a fellowship included the terms under which the money was granted. 
Discussion of a Rockefeller fellowship program in public health began in May 1915 when the Executive Committee of the International Health Board rendered an opinion that

the Board and other public health agencies in the United States [are] handicapped in the development of programs due to the fact that there [are] no schools where men could receive the special training to equip them properly for the responsibilities of public health workers (FELLOWSHIP REPORT 1931, 9 April 1932).

Although this opinion was focused on the public health situation in the United States, the Rockefeller philanthropies were at the same time assessing the public health situation in China and Brazil. Recognizing that those two large nations had serious public health problems, and also expecting that Rockefeller activities in those nations could have influence throughout East Asia and South America, respectively, the Foundation sent commissions of its advisors to China and Brasil to report on conditions and to make recommendations for action. Both commissions returned to urge the implementation of fellowship programs to train promising young public health officials and medical professionals at leading schools of public health in the United States and, when appropriate, in Canada and Europe (FODSICK, 1952, p. 84-86; MATYSIAK, 2014, p. 87-89; ROCKEFELLER FOUNDATION, 1917, p. 171-172). ${ }^{\text {viii }}$

The exigencies of war in Europe and elsewhere slowed the implementation of the fellowship program, but in January 1917 the trustees of the International Health Board resolved to provide "training in this country in medicine and public health of a limited number of men to be selected from time to time from the countries in which [the Board] may be seeking to promote the development of agencies for the relief and control of disease" (APPLEGET, 1932).

The formal public health program begun with three fellowships granted in 19171918 by the International Health Board, although many more fellowships were awarded by the China Medical Board, at that time a dependent of the Rockefeller Foundation, which was seeking to training a body of Chinese scientists and physicians to take leading roles in the newly-founded Peking Union Medical College. ${ }^{\text {ix }}$ The Rockefeller Foundation's Annual Report for 1918 noted, under the heading "International Fellowships and Scholarships," that in its publications granted to students from foreign countries or to American missionaries at home on furlough. Since 1915 it has been the policy of the Foundation to bestow stipends of this kind. In 1918 a total of $\$ 55,000$ was expended for this purpose. There were sixty-eight fellowships and scholarships... [sixty-five of which were 
the support of Chinese medicine, and three for Brazilian medicine] (ROCKEFELLER FOUNDATION, 1919, p. 48).

In justification, a few sentences later came this declaration:

\begin{abstract}
A study of the public health and medical education fields makes it clear that a largely augmented personnel of well-trained and experienced experts is a first requisite. The wise provision of stipends for the training of such persons is a fundamental contribution to progress in each nation, and may be a means of promoting international understanding and good will (ROCKEFELLER FOUNDATION, 1919, p. 49).
\end{abstract}

The president of the Rockefeller Foundation, George Vincent, echoed this expression in private correspondence when he commented that the Foundation had been "for some time interested in a plan for the exchange of students and professors... The Rockefeller Foundation is especially interested in exchanges [fellowships] in the fields of medicine and public health" (VINCENT, 27 August, 1918). These statements define the goals of the fellowship program as it was initiated: creating a globally-distributed corps of "well-trained and experienced experts" who will create "international understanding," particularly in "the fields of medicine and public health." understanding was determined in large part by the kinds of, and sites of, the fellows' training: in reality the program was heavily weighted toward sending fellows to institutions in the United States that also were recipients of Rockefeller funding and were woven into the Foundation's global strategy (FEE, 1983, p. 339-363; FEE, ACHESON, 1991, chapters $4,5,7)$.

\title{
The development of the Fellowship Program
}

By January 1921 only \$35,000 was appropriated for all fellowships, and it was July 1922 before the Foundation normalized the standards for awards, which included the right of the Foundation's staff to approve the place of study; the expectation that fellows would return to their country of origin after study; and that fellowships should be held in either the United States or in Europe, but not both. Fellowships of two years were expected (APPLEGET, 1932). This action, as well as the anticipated creation of the International Education Board by John D. Rockefeller Jr. in 1923, with the mission to promote the international diffusion of science, seemed to open the monetary floodgates. By the end of 1922 over \$100,000 had been allocated for public health fellowships, and funding doubled within four years (THE ROCKEFELLER FOUNDATION, 1944). Funding for the fellowship programs of all of the Rockefeller philanthropies jumped to $\$ 1,541,826$ in 1925 , 
with the public health fellowships a significant portion of that amount. Over the next 15 years an average of 90 new public health fellowships were awarded each year. Because most fellowships were for two years, and some were extended to three years, the program carried as many as 225 fellows in a year (FELLOWSHIP REPORT 1931, [1932]; ANNUAL FELLOWSHIP PROGRAM REPORTS..., 1940).

Thus, by the end of the 1930s the public health fellowship program had created a constituency of about 1500 former and current fellows: about a third were from the United States or Canada, with the rest from South America, Asia and Europe. Rarely were fellows from Africa, and few were from any colonial areas, except India. But fellowships in nursing should be added to this total, because most were in the public health field. That would bring the number of awardees from 1915-1939 to about 2000 (STATISTICAL SUMMARY... 1946).

\section{Characteristics of Fellows}

The largest portion of public health fellowships was given to persons already in the profession, or who were in a closely-related field of work. Fellows were expected to increase their knowledge and skills so that they could return to their home countries to make contributions to national public health capacities (STAPLETON, 2009, p. 74-75). Fellows were selected not only because they were believed to have outstanding ability, but also because their countries of origin promised to provide suitable employment for them when they returned (ROCKEFELLER FOUNDATION, 1922, p. 51-52, 145-146; 1931, p. 106). (The underdevelopment of public health infrastructure in many colonies - and the consequent inability to guarantee placement of fellows - may account for why few fellows came from colonies). The fellowship records are full of mentions of the posts that were promised to returning fellows, usually instructional or administrative positions. Some typical descriptions of the posts include: "it is expected that he will become assistant to the Director of the Laboratory of Bacteriology in the Ministry of Health" (Arnoldo Galbadon, Venezuela, 1935); "on his return to Cluj he will be doing work at the Institute of Hygiene" (Ilie Ardelean, Rumania, 1938); "Health Officer, City \& Province of Antofagasta" (Jorge Castillo Franke, Chile, 1942) (WARREN, 18 November 1935; MUENCH, 7 March 1938; FELLOWSHIP RECORDER CARD Castillo... s/d).

Overwhelmingly the fellowships were given for study in the United States (81\%), with Canada being the second-most frequent destination (11\%). Britain, France and Germany, combined, accounted for much of the rest (4\%). ${ }^{\mathrm{xi}}$ Essentially the fellowship 
program created a cadre of English-speaking professionals throughout the world, trained in American public health strategies and techniques, who were alumni of leading North American institutions. Often former fellows sent their own students or protégés to the same institutions. Although cumulative statistics are not available, it appears from a review of the annual reports of the fellowship program during the 1930s that the schools of public health to which most fellows were sent were Johns Hopkins University, Harvard University, and the University of Toronto, in that order. Other important destinations were the London School of Tropical Medicine and Hygiene, the Western Reserve University School of Nursing (Cleveland, Ohio, USA), Yale University, and the nursing program at the Teachers College of Columbia University (ANNUAL FELLOWSHIP PROGRAM REPORTS..., 1940).

Educational programs for the fellows were created by Rockefeller officials at the beginning of each fellowship, and were intended to prepare the fellows for the specific roles for which they were destined. ${ }^{x i}$ Fellows judged deficient in English were sent to tutors for several weeks before classes started. Often the fellows were scheduled for tours of public health offices and programs, usually before courses began, but also during summers, or occasionally after coursework was completed. Because fellows often arrived in New York City on a passenger ship at the beginning of their fellowships, or embarked for home from there, visits to that city's public health sites were frequently on their agendas. Those sites included the laboratories of the New York City Department of Health, the East Harlem Nursing and Health Service, and (beginning in 1929) the Rockefeller Foundation's Virus Laboratory located at the Rockefeller Institute for Medical Research.

\section{A Case Study: Lidia LaFace Antinoro}

A typical fellow for the fellowship era discussed here was Lidia LaFace Antinorio, an Italian entomologist who received a degree from the University of Rome in 1915. ${ }^{\text {xii }}$ In August 1929 she was recommended for a fellowship by George Strode, a Foundation officer. Strode's plan was for Mrs. Antinoro to study entomology at Johns Hopkins University (under Dr. F.M. Root), and then be placed in a temporary position at the Bureau of Entomology in the United States Department of Agriculture. She was expected on her return to Italy to take a position at the planned institute of hygiene that would be built with Rockefeller Foundation funds (STAPLETON, 2000, p. 130-133). She began her studies in October 1929, at the same time having private English instruction. Johns Hopkins 
University dutifully reported her grades to the Foundation after each of the semesters she attended: as an experienced entomologist it is not surprising that she was rated "excellent" in seven of her ten courses.

In March 1930 Mrs. Antinoro outlined her preferred summer course of field study in the collecting, preserving and examining insect specimens. At the Foundation's request Dr. Root made the arrangements for her, which included working for one week each at the Bureau of Entomology and the Bureau of Animal Husbandry of the Department of Agriculture in Washington, DC, followed by six weeks at the Douglas Lake Biological Station of the University of Michigan. She then returned to Johns Hopkins, where the Foundation recommended that her classwork be combined with "lab[oratory] experiments in Genetics" under Professor Alexander Weinstein. He was known to the Foundation because he had held both National Research Council and International Education Board fellowships in genetics. He had been a student of Thomas Hunt Morgan, and has been described as one of the "Drosophila elite" whose studies of the fruit fly were the epitome of the genetics of the time (KOHLER, 1994, p. 93).

Although the Foundation archives provide only brief summaries of her fellowship work, there is some evidence that Mrs. Antinoro not only received Foundation guidance, but that she also attempted to shape elements of the fellowship on her own terms. By the spring of 1931, for example, Mrs. Antinoro had been given two extensions of her fellowship, and she argued for a continuation of her studies at Johns Hopkins in order to obtain a doctorate. The archival record notes that she was "greatly disturbed" that she had been denied a third fellowship extension that would have permitted her to do so. Instead, she was awarded a lesser degree. ${ }^{\text {xiv }}$

The Foundation's denial of the third extension may have been a response to the urgent request from Lewis Hackett and Alberto Missiroli, at the Rockefeller-funded Stazione Sperimentale per la Lotta Antimalarica in Rome, for Mrs. Antinoro's assistance in their laboratory. Hackett, a Rockefeller officer who co-founded the Stazione, stated that "there are few entomologists at present in Italy. [Antinoro] will occupy a position of strategic value in medical entomology upon her return." She did soon join the staff of the Stazione, and also took an appointment at the University of Rome. After the Rockefellerfunded Istituto di Sanita Pubblica opened in Rome in 1933, Mrs. Antinoro moved there, as had been anticipated when she was given the fellowship, and she remained at there (and at its successor, the Istituto Superiore di Sanita) teaching entomology for three decades. 


\section{Field Stations and Laboratories}

A favorite assignment that the Foundation gave many fellows was a two-week visit (or longer, as with Mrs. Antinoro) to an experimental site or a laboratory, often one operated by the Foundation. Because most fellows were trained in North America, the preponderance of those visits were there. In the 1920s the Rockefeller philanthropies created a number of public health entities that were designated as "field stations." The term derives from the growing practice in the latter $19^{\text {th }}$ century of establishing agricultural and biological research facilities in sites where specimens were abundant or where experiments and trials could be carried out with a minimum of outside interference. ${ }^{\mathrm{xv}}$ Rockefeller-related field stations were created across the globe for varying periods of time and with varying research programs. Malaria projects in the 1920s and 1930s, for example, included field stations at Leesburg, Georgia, USA; Tallahassee, Florida, USA; Edenton, North Carolina, USA; Petrich, Bulgaria; on the island of Corsica, France; Rome, Italy, which had several satellite stations; and at Novaliches, Philippines. These and other field stations were regarded by Lewis Hackett, a leading office of the Rockefeller Foundation, as the lifeblood of its public health work (FARLEY, 1995, p. 217).

Over the years the Rockefeller Foundation gradually changed its public health emphasis in the field from applied research to laboratory-focused research. Laboratories were set up at Lagos, Nigeria; São Salvador, Brazil; and Tallahassee, Florida, USA. A major laboratory, usually known as the Virus Lab, was created at the Rockefeller Institute for Medical Research in New York City, New York, USA, for undertaking fundamental research on yellow fever, malaria, influenza, and typhus (FARLEY, 1995, p. 203-221; STAPLETON, 2005, p. 513-540).

\section{A Case Study: The Andalusia Field Station}

Late in 1922 the International Health Board, one of the philanthropies coordinate with the Rockefeller Foundation, established a training facility at Andalusia, Alabama, USA, for the dual purposes of training members of its staff in applied public health strategies, and providing a demonstration of "methods of rural health administration" (ANNUAL REPORT of... 1923; SMILLIE, 1924). Headed by W.G. Smillie, a physician, the station became an important site for teaching the array of anti-hookworm techniques that the Rockefeller philanthropies had developed, and also for the broader task of introducing public health officials to the range of actions required for effective public health 
programs. The Rockefeller approach to public health included standardizing the methods of collecting data on actual health and sanitary conditions in the field.

In its first year of operations the Andalusia station had substantial visits from seven public health fellows, including two from Australia, and one each from Brazil, China, Mauritius, the Netherlands, and the USA. A group of visitors from a League of Nations meeting in Washington, DC, USA, included representatives from another thirteen nations (ROCKEFELLER FOUNDATION, 1924, p. 14). In the second year of the station's operation Dr. Smillie reported that the following groups or individuals had spent weeks or, in some cases, months there: thirteen Rockefeller staff members; eleven possible future Rockefeller staff members; twenty-two health workers and five public health nurses from the USA; and eleven Rockefeller public health fellows, including four from Brasil, three from China, two from the Netherlands East Indies, and one each from Canada, Italy, and Spain. ${ }^{\mathrm{xi}}$ In addition, several people visited the station briefly, including public health officers from Australia, Britain, Denmark, France, the Straits Settlements, and Sweden; four United States Public Health Service officers; five state health officials from the USA; and various others whose origins were not noted. In all there were 124 trainees and visitors at the Andalusia station in 1924 (SMILLIE, 1924; SMILLIE, 29 December 1924).

Two years later, in 1926, the Andalusia station remained highly active, with a total of 130 trainees and visitors. ${ }^{\text {xii }}$ For this essay, there will be a focus on the seventeen foreign visitors to the station in that year. They came from Austria, Brasil, Bulgaria, Canada, Columbia, Italy, Japan, Nicaragua, Norway, Puerto Rico, Rumania, and Spain (LEACH, 1926). Eight of them could be documented as fellows, and the following is a summary of their circumstances and experiences. ${ }^{\text {xviii }}$ All were men; six were married and two were single. They were between 28 and 40 years of age during their visit to the station. All had degrees in medicine, and all were wokring in the public health field at the time of their fellowship appointments. Five were in administration; two were teaching; and one had both responsibilities. All received one-year fellowships, and three had their fellowships extended for a second year.

Some in the group began their fellowship tenures with tutoring in English, and while the record indicates that language remained a difficulty for several of them, the majority did well in their classes. Seven were enrolled at the Johns Hopkins School of Public Health; one was at the Harvard University School of Public Health. Four were nonmatriculated students; four were in degree programs, and three of those received degrees. Outside of their studies, six of the fellows visited sites other than Andalusia; one 
spent considerable time after his fellowship visiting the Institut Pasteur in Paris, and then the Institut's field station in Tunis.

While most of the group appear to have accepted the arrangements made for them by the Rockefeller staff, some negotiated aspects of their programs or made special travel arrangements. One "wish[ed] to spend two months in visiting state, municipal and county health organizations in order that he may gain practical experience" (FELLOWSHIP RECORDER CARD Fontanelle, s/d). Another asked to be sent from Andalusia to another site after he had finished what he considered the most challenging portion of the work there.

Three of the fellows encountered what appear to be ethnic or racial assessments of their visits to Andalusia. Dr. Smillie's comments regarding the fellows from Japan, Nicaragua and Puerto Rico were quite disparaging ("lazy, superficial”; "difficult to keep him working"; "did not appear disposed to work"), while those same fellows later received positive comments from other observers. The xenophobia rampant in the United States in the 1920s, combined with the strict racial segregation in the American South, are likely reasons why foreigners at Andalusia would have found themselves in an unwelcome environment. Yet there is no indication in the archival record that the Rockefeller Foundation recognized, or tried to ameliorate, their reception at Andalusia.

All of the fellows returned to their to positions elevated above those they held previous to their fellowships: the Rockefeller Foundation diligently documented their subsequent careers. All but one found permanent appointments in teaching or administration that fulfilled the expectations of the fellowship program. A sample of the public health fellowships indicates that the program in general also met its goals, in that at least $75 \%$ of the fellows from outside of the United States and Canada had subsequent careers in public health administration or public health education in their native countries. ${ }^{\text {xix }}$

\section{Visiting in General}

The Rockefeller philanthropies encouraged travel and visiting of all kinds, usually drawing on the hospitality of the institutions they funded, but sometimes other institutions that they judged to be friendly. As one office in the Paris office of the Foundation described his experiences when writing to a colleague at the home office in New York City, "you may from time to time have similar visitors to those who come to this office and who wish the entrée through the Foundation to many institutions, and whom it is difficult to refuse" (O'BRIEN, 1930). Although a professor at University College, London, complained to the Foundation that "we find occasional visitors a great trouble, and we do not see why they should steal our time with no compensating advantage to us," most institutions and 
individuals, whether out of collegiality or the hope of future Rockefeller funding, were receptive to visits from Rockefeller fellows (PERSON, 1930).

\section{Reflections and Conclusions}

Perhaps the most important observation to make about the fellowship program and the site-visiting encouraged by the Rockefeller Foundation and its associated philanthropies is that they were based on the understanding that observation and participation are critical aspects of learning. To begin with, fellows studying at foreign universities probably had classroom experiences significantly different than they had in their countries of origin and probably implemented some of those new experiences in their curricula on returning home. But in addition, learning techniques, whether in the university laboratory or in the field, were important additions to their public health armamentarium. Formal education in scientific medicine was a necessary preparation in the view of the Rockefeller officers, but field visits were a critical means of inculcating the transfer and diffusion of the knowledge that the Rockefeller Foundation wanted to globalize.

The hoped-for results of fellowships were suggestively summarized in a memorandum written by Rockefeller office Alan Gregg, probably in 1928, instructing fellows completing their fellowships to write short reports on their "experiences and impressions." Gregg stated that "reports form our foreign fellows in the past have been especially helpful" because (1) fellows had described "differences in emphasis or orientation... in comparison to their department their own medical faculty"; (2) "fellows have seen ... new appliances, apparatus or technical methods which are of especial value in their future work"; and (3) "many of the fellows have taken a very intelligent and profitable interest in the teaching methods that they have seen abroad or in the organization of laboratory or classroom work" (GREGG, 1928).

Less engaged in this essay, but also important, was the deepening and broadening of international communication in the public health field that was fostered by fellowships and visits. Anyone studying the history of the Rockefeller public health fellowships will observe the importance of the web of relationships developed between former fellows, grantees, and Rockefeller-funded public health institutions. A global conversation on public health emerged in the decades of the 1920s, 1930s, and 1940s that would have been inconceivable in previous years. That web of relationships was vividly experienced by Ookeh Khaw, a parasitologist from the Rockefeller-funded Peking Union Medical College in Beijing, who in 1933 was traveling through Europe on a Rockefeller fellowship. On a stop in Spain to study public health projects there he reported that 
One of the Divisional Inspectors - a Rockefeller Foundation fellow of Johns Hopkins - came with me, so that besides being received with kindness hospitality everywhere - I saw not only anti-malaria work but other public health activities as well. The latter are receiving feverish attention and are carried out in approved American style as most of the heads [of public health units] are R[ockefeller] F[oundation] fellows (KHAW, 6 June 1933).

Clearly, the dimensions of the Rockefeller public health fellowship program exceeded any similar program of its time, and any discussion of its effects need to take into account its unprecedented reach and scope. By 1929 international fellowships of a similar type probably numbered less than a hundred, while the Rockefeller entities were regularly supporting more than five hundred directly, and two hundred indirectly through the support of other organizations (VAN WESP, 1929; FELLOWSHIPS..., 1930).

Over three decades in the first half of the $20^{\text {th }}$ century the Rockefeller philanthropies spent millions of dollars on public health fellowships and expended a great deal of time and effort to promote and support visits to its public health facilities and program sites. The fellowship program provided the possibility of working with promising public health professionals wherever they were found across the globe, and subsequently inserting them into national or colonial infrastructures. The Rockefeller public health fellowship program was remarkably successful at meeting its goals - and possibly made the greatest contribution to the transfer and diffusion of public health knowledge in the $20^{\text {th }}$ century (TOURNÈS, 2006, p. 78). Any consideration of long-term change in the global public health infrastructure of the 21 st century would do well to consider whether a similar commitment is required today.

\section{References}

ABRAHAMSON, E. J. Beyond charity: a century of philanthropic innovation. Rockefeller Foundation Centennial Series. New York: Rockefeller Foundation, 2014.

ANDERSON, W. Remembering the Spread of Western Science. Historical Records of Australian Science, Melbourne, 2018. Available in: https://hss.sas.upenn.edu/sites/default/files/Anderson $\% 202018 . \% 20$ Remembering\%20the\%20Spread\%20ofWestern\%20Science.pdf. Accessed in: 22 February 2021.

ANNUAL FELLOWSHIP PROGRAM REPORTS, 1932-1939. Folders 279-281, Box 37, Series 100E, RG 1.2, RFA, 1940.

ANNUAL REPORT of the training base of the International Health Board, Andalusia, Alabama. Folder 28, Box 4, Series 201, RG 5.2, RFA, 1923.

APPLEGET, T. B. Report on Fellowship Programs of the Rockefeller Foundation. Folder 318, Box 43, Series 100E, RG 1.2, RFA, 1932. 
ASSMUS, A. The creation of postdoctoral studies and the siting of American scientific research. Minerva, n. 31, p. 151-183, 1993.

BIRN, A. Public health or public menace? The Rockefeller Foundation and Public Health in Mexico, Voluntas, v. 7, n; 1, 1996.

BIRN, A. Wa(i)ves of Influence: Rockefeller Public Health in Mexico, 1920-1950. Stud. Hist. Phil. \& Biomed. Sci., v. 31, n. 3, p. 381-395, 2000.

CHERNOW, R. Titan: the life of John D. Rockefeller, Sr. New York: Vintage Books, 1998.

CUETO, M. The cycles of eradication: the Rockefeller Foundation and Latin American public health, 1918-1940. In: WEINDLING, P. (Ed.). International health organisations and movements, 1918-1939. Cambridge: Cambridge University Press, 1995.

DEACON, M. B. Oceanographic institutions. In: HEILBRON, J. L. (Ed.). The Oxford companion to the History of Modern Science. USA: Oxford University Press USA, p. 596-598, February 14, 2003.

DR. W.G. SMILLIE, 27 January 1927. F.F. Russell Diary, RG 12.1, RFA, 1927.

DUTIES AND RESPONSIBILITIES of Fellowship Service. Folder 217, Box 29, Series 100E, RG 1.2, RFA, 1927.

FARLEY, J. The International Health Division of the Rockefeller Foundation: the Russell years. In: WEINDLING, P. (Ed.). International health organisations and movements, 1918-1939. Cambridge: Cambridge University Press, 1995.

FEE, E. Competition for the first School of Hygiene and Public Health. Bulletin for the History of Medicine, v. 57, n. 3, p. 339-363, 1983.

FEE, E; ACHESON, R. M. (Eds.). A history of education in public health: health that mocks the Doctors' rules. Oxford: Oxford University Press, 1991.

FELLOWSHIP RECORDER CARD Castillo (Franke), Dr. Jorge. Fellowship recorder files, RFA. s/d.

FELLOWSHIP RECORDER CARD Fontanelle, Dr. Jose Paranhos. Fellowship recorder files, RFA. s/d.

FELLOWSHIP REPORT 1931. Folder 316, Box 43, Series 100E, RG 1.2, RFA, 9 April 1932.

FELLOWSHIP REPORT 1931. Folders 279-281, Box 37, series 100E, RG 1.2, RFA, [1932].

FELLOWSHIPS. Rockefeller Boards. 1915-1929. Folder 218, Box 29, Series 100E, RG 1.2, RFA, 1930.

FOSDICK, R. The story of the Rockefeller Foundation. New York: Harper \& Brothers, 1952.

GAUDILLIÈRE, J. Paris - New York roundtrip: transatlantic crossings and the reconstruction of the biological sciences in post-war France. Stud. Hist. Phil. Biol. \& Biomed. Sci. v. 33 p. 389-407, 2002.

GREGG, A. Short report at the termination of your foreign studies. Folder 217, Box 29, Series 100E, RG 1.2, RFA, 1928.

JEREMY, D. J. (Ed.). International Technology Transfer: Europe, Japan and the USA. Aldershot: Edward Elgar, 1991. 
KHAW, O. K. to Roger Greene. v. 1312, Peking Union Medical College Archives, Beijing, PRC, 6 June 1933.

KOHLER, R. E. Lords of the fly: drosophila genetics and the experimental life. Chicago: University of Chicago Press, 1994.

LEACH, C. N. Annual Report, International Health Board Training Station for Health Officers, 1926. Folder 28, Box 4, Series 201, RG 5.2, RFA, 1926.

MATYSIAK, A. Health \& Well-Being: science, medical education and Public Health. New York: Rockefeller Foundation, 2014.

MILLER, H. S. Science and Private Agencies. In: VAN TASSEL, D. D.; HALL, M. G. (Eds.). Science and society in the U.S. Dorsey: Homewood, III., 1966.

MUENCH, H. to J. H. Bauer. Folder 372, box 34, RG 5.4, RFA, 7 March 1938.

NAKAYAMA, S. Diffusion in the East. In: HEILBRON, J. L. (Ed.). The Oxford companion to the History of Modern Science. Oxford: Oxford University Press, 2003.

O'BRIEN, D. P. to W. S. Carter. Folder 218, Box 29, Series 100E, RG 1.2, RFA, 11 June 1930.

PERSON, K. to D.P. O'Brien, 5 June 1930, attached to D.P. O'Brien to W.S. Carter, 11 June 1930. Folder 218, Box 29, Series 100E, RG 1.2, RFA, 5 June 1930.

ROCKEFELLER FOUNDATION, Annual Report for 1930. New York: Rockefeller Foundation, 1931.

ROCKEFELLER FOUNDATION. Annual Report for 1916. New York: Rockefeller Foundation, 1917.

ROCKEFELLER FOUNDATION. Annual Report for 1918. New York: Rockefeller Foundation, 1919.

ROCKEFELLER FOUNDATION. Annual Report for 1919. New York: Rockefeller Foundation, 1920.

ROCKEFELLER FOUNDATION. Annual Report for 1921. New York: Rockefeller Foundation, 1922.

ROCKEFELLER FOUNDATION. Annual Report for 1923. New York: Rockefeller Foundation, 1924.

ROCKEFELLER FOUNDATION. Annual Report for 1930. New York: Rockefeller Foundation, 1931.

ROCKEFELLER FOUNDATION. Directory of Fellowships and Scholarships, 19171971. New York, 1972.

ROGERS, E. Diffusion of innovations. 5. ed. New York: Free Press, 2003.

SAUNIER, P. Transnational history. Basingstoke: Palgrave Macmillan, 2013.

SMILLIE, W. G. to F. F. Russell. Folder 26, Box 4, Series 201, RG 5.2, RFA, 29 December 1924.

SMILLIE, W.G. Second Annual report of the Training Station of the International Health Board at Andalusia, Alabama. Folder 28, Box 4, Series 201, RG 5.2, RFA, 1924.

STAPLETON, D. H. A lost chapter in the early history of DDT: the development of Antityphus technologies by the Rockefeller Foundation's Louse Laboratory, 1942-1944.

Technology and Culture, v. 46, n. 3, p. 513-540, 2005. 
STAPLETON, D. H. Internationalism and nationalism: the Rockefeller Foundation, public health, and Malaria in Italy, 1923-1951. Parassitologia, v. 42, p. 130-133, 2000.

STAPLETON, D. H. 'An International contribution to medical education': the global context of the Peking Union Medical College. In: BULLOCK, M. B. (Ed.). The legacy of PUMC: centennial essays. p. 19-36. Beijing, 2017.

STAPLETON, D. H. Malaria eradication and the technological model: the Rockefeller Foundation and public health in East Asia. In: YIP, K. (Ed.). Disease, colonialism and the State: malaria in Modern East Asia. p. 74-75. Hong Kong, 2009.

STAPLETON, D. H. The transfer of early industrial technologies to America. Philadelphia: American Philosophical Society, 1987.

STATISTICAL SUMMARY of Fellowships, 1915-1945: Thirty Year Review. Folder 320, Box 43, Series 100E, RG 1.2, RFA, 1946.

THE ANNUAL REPORT for 1926 of the Hookworm research laboratory. Folder 30, Box 4, series 201, RG 5.2, RFA, [1927].

THE ENCYCLOPEDIA BRITTANICA. $11^{\text {th }}$ ed. New York, 1910.

THE ROCKEFELLER FOUNDATION. Fellowship policies and programs. Folder 218, Box 29, Series 100E, RG 1.2, RFA. 8 February 1929.

THE ROCKEFELLER FOUNDATION. Fellowships: expenditures for the years 1915 to 1953 and appropriations for 1944. Folder 221, Box 29, Series 100E, RG 1.2, RFA, 1944.

TOURNÈS, L. Le reseau des bousiers Rockefeller et la recomposition des savoirs biomédicals en France (1920-1970). French Historical Studies. n. 29, winter 2006.

VAN WESP, H. Memorandum on fellowships. Folder 218, Box 29, Series 100E, RG 1.2, RFA, [January] 1929.

VINCENT, G. E. to John D. Rockefeller Jr. Folder 217, Box 29, Series 100E, Record Group [hereafter RG] 1.2, Rockefeller Foundation Archives [hereafter RFA], Rockefeller Archive Center [hereafter RAC], Sleepy Hollow, New York, USA. 9 November, 1923.

VINCENT, G. E. to Richard M. Pearce. Folder 217, Box 29, Series 100E, RG 1.2, RFA. 27 August 1918.

WARREN, A. J. to J. H. Bauer. Folder 372, Box 34, RG 5.4, RFA, 18 November 1935.

WEINDLING, P. (Ed.). International health organisations and movements, 1918-1939. Cambridge: Cambridge University Press, 1995.

WIK, R. M. Science and American Agriculture. In: VAN TASSEL; DAVID D., Hall, eds., Science and Society in the United States. In: VAN TASSEL, D. D.; HALL, M. G. (Eds.). Science and society in the U.S. Dorsey: Homewood, III., 1966.

Recebido: 01/07/2021

Aceito: $25 / 07 / 2021$

Publicado:01/09/2021

\footnotetext{
${ }^{i}$ Darwin H. Stapleton, Ph.D., is a widely-published historian of technology, science and public health. He was the Executive Director of the Rockefeller Archive Center, 1986-2008. His scholarship does not represent the views and policies of the Rockefeller Foundation. orcid.org/0000-0002-2864-1796. Email: darwin.stapleton@yahoo.com.
} 
ii The standard history of the Rockefeller Foundation for many years was Raymond Fosdick's The Story of the Rockefeller Foundation (1952). The recent official centennial history uses "memory to help us see into the future"(ABRAHAMSON, 2014, p. 21). In the same series, with a focus on public health is: Matysiak (2014).

iii See Weindling (1995), especially chapters 4, 7, 10, 11, 13.

${ }^{\text {iv }}$ A standard reference work on the subject is: Rogers (2003). A reconsideration of the historiography of the diffusion of Western science can be found in: Anderson (2018). See also: Nakayama (2003, p. 208-212); Assmus (1993, p. 151-183); Gaudillière (2002, p. 389-407).

${ }^{v}$ That is especially true for the history of technology. A useful set of essays is in: Jeremy (1991). See also: Stapleton (1987).

${ }^{v i}$ Among many publications that mention the Rockefeller bent toward scientific medicine in public health is: Birn (1996, p. 39).

vii S.v., "Fellow," in: The Encyclopedia ..., 1910, p. 243. The Tyndall Fund, established in 1872, endowed "one of the first postgraduate fellowships available to American men of science," although it is not clear whether initially it was called a fellowship. See: Miller (1966, p. 210-211).

viii Note that in 1919, at an early stage of the fellowship program, seven of the twenty-eight fellowships in public health were awarded to Brazilians: Rockefeller Foundation (1920, p. 112).

ix Even earlier the China Medical Board had awarded some fellowships in China: Appleget (1932). See also: Stapleton (2017, p. 19-36). A Chinese-language version is on p. 3-18.

${ }^{x}$ See also the outline statement of the goals for the fellowship program in: The Rockefeller Foundation, 8 February 1929.

${ }^{x i}$ Calculated from Statistical Summary (1946).

xii The initial assistance and direction given to fellows are summarized in: Duties and Responsibilities..., 1927.

xiii The following information is taken from "Antinoro, Mrs. Lidia LaFace," fellowship recorder files, RFA.

xiv The extensive fellowship files of the Rockefeller Foundation were discarded in the 1950s and 1960s, leaving only the fellowship recorder cards and ancillary correspondence to document the fellowships. The full files would have revealed the "accommodation, welcoming, resistance, negotiation, molding and refusal" that are hinted at in the case of Lidia LaFace Antinoro: Birn (2000, p. 381).

${ }^{x v}$ For example, see a discussion of oceanographic research stations: Deacon (2003, p. 556-598). The United States' Hatch Act of 1887 created the Office of Experimental Stations in the Department of Agriculture that began a tradition of field research in numerous areas of plant and insect biology: Wik (1966, p. 95).

xvi The countries of origin for the fellows are listed in: Smillie, 29 December 1924.

xvii The office of the station had been moved to Montgomery, Alabama, USA, although the field laboratory remained at Andalusia. See: THE ANNUAL REPORT...[1927]. See also: entry for Dr. W.G. Smillie, 27 January 1927.

xviii Identified as fellows from the fellowship recorder cards, RFA: "Britto, Dr. Oscar Pereira de" (Brasil); "Fontenelle, Dr. Jose Paranhos" (Brasil); "Luengo, Dr. Emilio" (Spain); "Marginesu, Dr. Pasquale" (Italy); "Parrot, Dr. Paul" (Canada); "Perez, Dr. Jacinto, Jr." (Nicaragua); "Ramirez, Dr. Ramon Eladio" (Puerto Rico); "Saito, Dr. Kiyoshi” (Japan).

xix The sample was taken from: Rockefeller Foundation (1972). The directory is an alphabetical listing of all fellows, with information on nationality, fellowship year, and subsequent employment. The author's sample was based on public health fellowships found on every tenth page of the directory, beginning on page 13. The sample totaled 88 fellows from outside the United States and Canada. 